\title{
Congenital Eyelid Ptosis
}

National Cancer Institute

\section{Source}

National Cancer Institute. Congenital Eyelid Ptosis. NCI Thesaurus. Code C27049.

The drooping of the upper or lower eyelid that is present at the time of birth. 